Original Research Paper

\title{
Stomatal Characteristics of 5 Citrus L. Species (Rutaceae) From Pekanbaru, Riau Province
}

\author{
Nery Sofiyanti $^{1^{*}}$, Putri Intan Wahyuni ${ }^{1}$, Dyah Iriani ${ }^{1}$ \\ ${ }^{1}$ Department of Biology, Faculty of Math and Natural Resources Science, Universitas Riau, Pekanbaru, \\ Riau, Indonesia
}

\author{
Article History \\ Received : November 09 ${ }^{\text {th }}, 2021$ \\ Revised : December $15^{\text {th }}, 2021$ \\ Accepted : December $25^{\text {th }}, 2021$ \\ Published : January $10^{\text {th }}, 2022$ \\ *Corresponding Author: \\ Nery Sofiyanti, \\ Department of Biology, Faculty \\ of Math and Natural Resources \\ Science, Universitas Riau. \\ Pekanbaru, Riau, Indonesia \\ Email: \\ nery.sofiyanti@lecturer.unri.ac.id
}

\begin{abstract}
Stomata of leaf is one of the important trait in plant taxonomic study. This trait can be used to characterisize the members of a plant group including Citrus. This genus is one of fruit plant that commonly known in Pekanbaru, Riau. The aim of this study was to examine the characteristic of stomata of 5 Citrus species from Pekanbaru, Riau Province, Indonesia. Leaves were collected from the field. The stomatal preparations were conducted using replica method. Stomata were then observed and photographed using Mikroskop Binokuler Olympus CX23 and Mikroskop LCD Digital Celestron Model 44340. The results show that stomata of all Citrus species examined in this study shows the similar type, hypostomatic with reniform-shaped stomata. However, the variations are found in stomata density and index, as well as the length and length of stomata. $C$. hystrix and C. aurantifolia have the lowest $\left(419.89 / 1 \mathrm{~mm}^{2}\right)$.), and the highest stomatal density $\left(685.89 / 1 \mathrm{~mm}^{2}\right)$.), respectively. The size of stomata varies within the species. C. microcarpa has the biggest stomata size $(20.5 \times 18.5 \mu \mathrm{m})$. Stomatal density of Citrus examined in this study are high $\left(>500 / \mathrm{mm}^{2}\right)$ in C. aurantifolia and $C$. limon) and medium $\left(300-500 / \mathrm{mm}^{2}\right)$ in $C$. amblicarpa, $C$. hystrix and $C$. microcarpa. The density, index and size of stomata can be used to characterize each Citrus members that examined in this study.
\end{abstract}

Keywords: Citrus, Riau, Stomata

\section{Pendahuluan}

Citrus L. merupakan alah satu genus tumbuhan dalam Famili Rutaceae (Mabberley 2004) yang tersebar di daerah tropis dan sub tropis (Al-Anbari et al. 2015). Pada umumnya jenis-jenis dari genus ini merupakan jenis yang berhabitus semak atau pohon kecil, batang berduri (Musara et al. 2000), berdaun tunggal atau majemuk dan menghasilkan buah dengan tipe hesperidium. Variasi morfologi pada Citrus cukup tinggi (Yulianti et al. 2020; Husaain et al. 2021), demikian juga karakter anatominya seperti karakter stomata. Stomata (jamak) atau stoma (tunggal) merupakan celah/bukaan yang berada pada epidermis, yang dikelilingi oleh 2 buah sel "guard cells" (He \& Liang 2018). Stoma berasal dari Bahasa Latin yang berarti "mulut" (Kirkham 2014).
Menurut Avci dan Aygun (2014), stomata menghubungkan bagian luar dan dalam tumbuhan. Oleh karena itu, pada tumbuhan, stomata mempunyai fungsi sebagai tempat pertukaran gas, respirasi dan transpirasi. Stomata dapat dijumpai disemua bagian tumbuhan (kecuali akar), namun sebagian besar stomata ditemukan pada daun (Avci \& Aygun 2014).

Karakteristik stomata pada tumbuhan dapat dijadikan karakter penting dalam membantu identifikasi dan klasifikasi tumbuhan tersebut. Hal ini dikarenakan setiap jenis tumbuhan mempunyai karakteristik stomata yang berbeda dengan jenis lain. Pada anggota Rutaceae, termasuk genus Citrus, variasi stomata sering dijumpai pada 1 jenis (Aina \& Malik 2013). Oleh karena itu, kajian karakteristik stomata Citrus sangat penting 
untuk dilakukan agar memberikan data yang lengkap pada karakter ini. Tujuan dari penelitian ini adalah untuk mengetahui karakteristik stomata dari 5 jenis Citrus yang ditemukan di Pekanbaru, Riau.

\section{Bahan dan Metode}

\section{Pengambilan sampel}

Pengambilan sampel daun Citrus mengacu pada Aina \& Malik (2013). Tabel 1 menyajikan jenis Citrus di Pekanbaru, Riau yang diambil sampel untuk pembuatan preparat stomata. Setiap jenis diambil 5 helai daun dewasa yang mempunyai kondisi baik. Pengamatan stomata dilakukan dibagian abaxial dan adaxial daun, masing-masing pada 3 bagian yaitu bagian pangkal, bagian tengah dan ujung daun untuk mengetahui persebaran dari stomata pada setiap jenis Citrus yang diamati pada penelitian ini.

Tabel 1. Daftar jenis Citrus yang diteliti

\begin{tabular}{cll}
\hline No & \multicolumn{1}{c}{ Nama Jenis } & \multicolumn{1}{c}{ Nama Daerah } \\
\hline 1. & Citrus aurantiifolia (Christm.) Swingle & Jeruk Nipis; Limau Nipis \\
2. & Citrus hystrix DC. & Jeruk Purut \\
3. & Citrus limon (L.) Osbeck & Jeruk Lemon \\
4. & Citrus microcarpa Bunge & Jeruk Kasturi; Kasturi Minum \\
5. & Citrus amblycarpa (Hassk). Ochse & Jeruk Limau; Jeruk Saring; Kasturi Sambal \\
\hline
\end{tabular}

\section{Pembuatan preparat stomata}

Metode yang digunakan dalam pembuatan preparat stomata mengacu pada Haryanti (2010), yaitu metode replika. Daun dicuci bersih dan dikeringkan menggunakan tisu. Kutek bening dioleskan pada bagian bawah, tengah dan ujung daun, kemudian dikering anginkan. Kemudian selotip bening ditempelkan pada bagian daun yang sudah diolesi kutek, lepas selotip perlahanlahan dan tempelkan pada gelas benda untuk diamati. Pengamatan dan dokumentasi stomata dilakukan dengan menggunakan Mikroskop Binokuler Olympus CX23 dan Mikroskop LCD Digital Celestron Model 44340.

\section{Pengukuran data}

Kerapatan stomata diukur dengan cara menghitung jumlah stomata yang diamati pada setiap bidang pandang. Kemudian hasil yang diperoleh dikonversikan ke dalam $1 \mathrm{~mm}^{2}$. Rumus untuk mengitung kerapatan stomata mengacu pada Willmer (1983) yaitu sebagai berikut.

$$
K S=\frac{\text { jumlah stomata }}{\text { luas bidang pandang }\left(1 \mathrm{~mm}^{2}\right)}
$$

$\mathrm{KS}=$ Kerapatan stomata
Untuk perhitungan persentase indeks stomata, digunakan rumus sebagai berikut (Wallis 1965).

$$
P I S=\frac{J S}{J S+J E} \times 100 \%
$$

Keterangan :

PIS $=$ persentase indeks stomata

$\mathrm{JS}=$ jumlah stomata

$\mathrm{JE}=$ jumlah sel epidermis

Perhitungan jumlah stomata dan jumlah episermis dilakukan per satuan bidang pandang dan dikonversikan ke $1 \mathrm{~mm}^{2}$. Untuk mendapatkan data kuantitatif panjang dan lebar stomata, dilakukan pengukuran pada 10 stomata setiap jenis yang diamati.

\section{Hasil dan Pembahasan}

\section{Tipe dan bentuk stomata}

Hasil penelitian ini menunjukan bahwa semua jenis Citrus yang diamati mempunyai tipe stomata hipostomatik. Menurut Richardson et al. (2017), stomata hipostomatik merupakan tipe stomata yang hanya ditemukan pada permukaan bawah (abaxial) daun. Gambar 1 dan 2 menunjukan dokumentasi lapisan epidermis atas 
(adaxial) (Gambar 1) dan epidermis bawah (abaxial) (Gambar 2) daun Citrus yang diamati pada penelitian ini. Dari kedua gambar tersebut dapat diketahui bahwa stomata hanya ditemukan pada epidermis bawah saja, sedangkan epidermis atas tidak ditemukan stomata pada semua jenis Citrus yang diteliti. Oleh karena itu, tipe stomata Citrus pada penelitian ini adalah hipostomatik. Hal ini sejalan dengan hasil penelitian stomata Citrus oleh yang dilaporkan oleh Aina dan Malik (2013) dan Inyama et al. (2015). Walaupun pada umumnya stomata famili Rutaceae adalah hipotomatik, namun tipe amphistomatik pernah dilaporkan oleh Ulukus dan Tugay (2018) pada genus Haplophyllum.

Gambar 2 menunjukan bahwa semua jenis Citrus pada penelitian ini mempunyai stomata berbentuk ginjal. Kajian stomata pada jenis Citrus lain seperti $C$. reticulata juga menunjukan bentuk stomata yang sama (berbentuk ginjal) seperti dilaporkan oleh Hazarika et al. (2002) dan Arshdeep et al. (2020). Secara umum, bentuk stomata pada tumbuhan adalah ginjal dan halter, namun bentuk halter merupakan karakteristik pada tanaman Poaceae (Mashau et al., 2013).

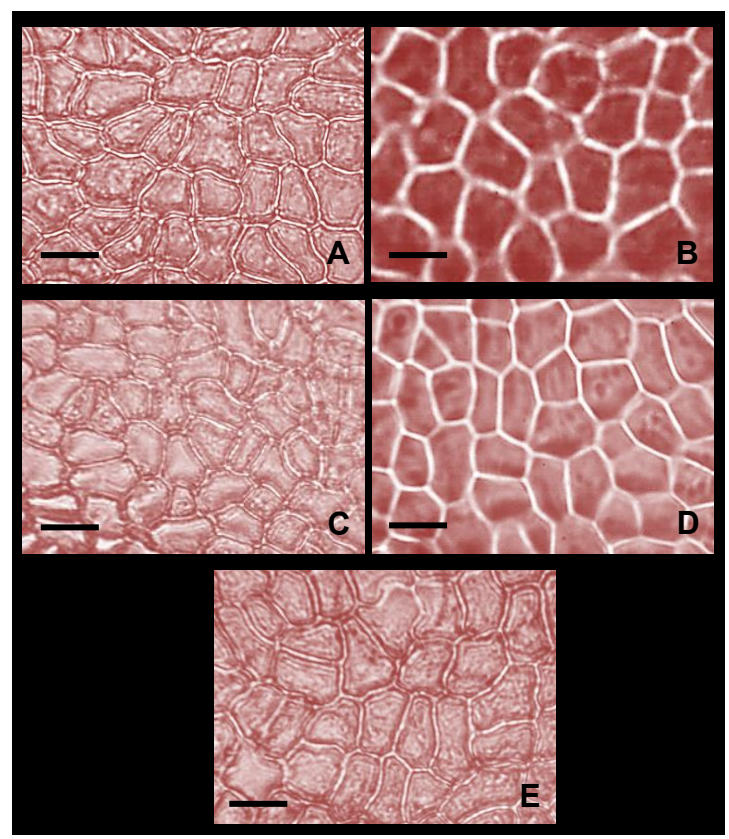

Gambar 1. Epidermis atas tanpa stomata. A. $C$. amblycarpa. B. C. aurantiifolia, c. C. hystrix, d. C. limon, e. C. microcarpa (skala $20 \mu \mathrm{m}$ ).

\section{Kerapatan, indeks dan distribusi stomata}

Kerapatan stomata merupakan jumlah stomata pada suatu bidang pandang. Semakin tinggi nilai kerapatan stomata suatu jenis tumbuhan maka semakin banyak jumlah stomatanya. Gambar 3 menyajikan histogram hasil pengukuran kerapatan stomata per $1 \mathrm{~mm}^{2}$, dengan rentang kerapatan stomata berkisar dari 419.89 (C. hystrix) sampai 685.08 (C. aurantifolia).

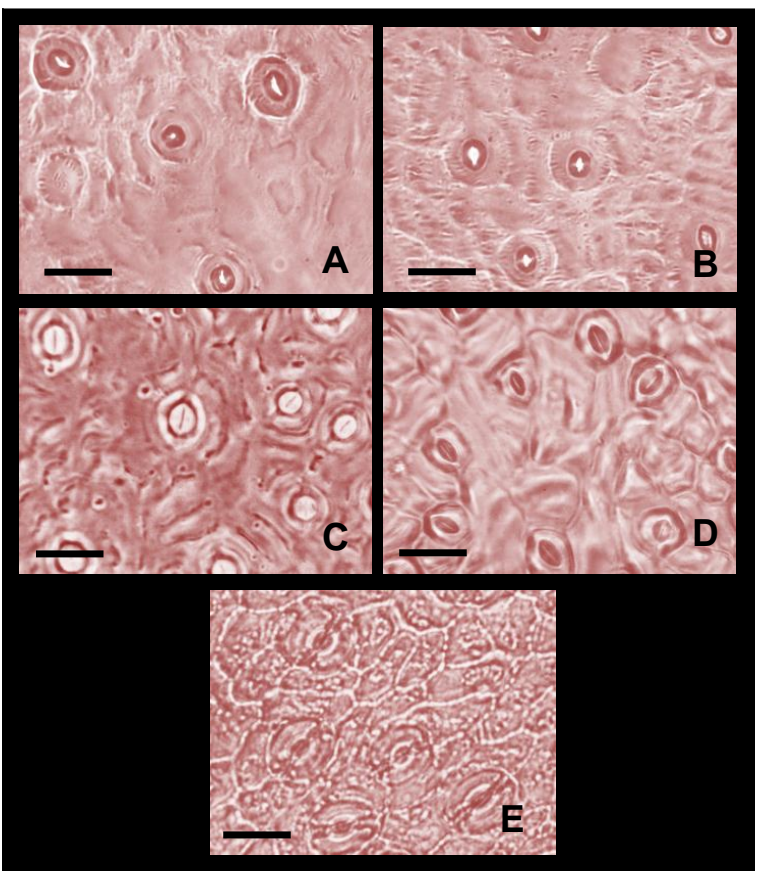

Gambar 2. Epidermis bawah yang menunjukan keberadaan stomata. A. C. amblycarpa. B. C. aurantiifolia, c. C. hystrix, d. $C$. limon, e. C. microcarpa (skala $20 \mu \mathrm{m}$ ).

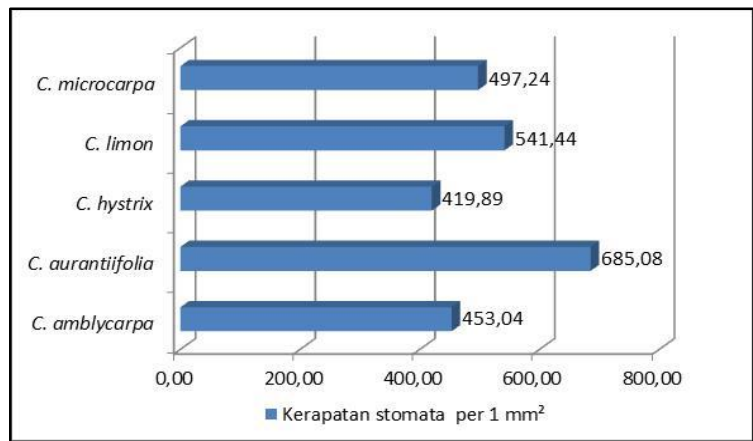

Gambar 3. Histogram kerapatan stomata 5 jenis Citrus 
Kerapatan stomata digolongkan menjadi 3 kelompok (Karubuy dkk. 2018) seperti disajikan pada tabel 2 berikut ini.

Tabel 2. Kelompok kerapatan stomata

\begin{tabular}{clc}
\hline No & Kerapatan stomata $/ \mathbf{m m}^{2}$ & Kelompok \\
\hline 1. & $<300$ & Rendah \\
2. & $300-500$ & Sedang \\
3. & $>500$ & Tinggi \\
\hline
\end{tabular}

Pada penelitian ini, ditemukan 2 kelompok kerapatan stomata yaitu kerapatan tinggi $(C$. aurantifolia dan $C$. limon) serta kerapatan sedang (C. amblicarpa, C. hystrix dan C. microcarpa). Tuasamu (2018) juga melaporkan kelompok yang sama pada $C$. hystrix dan C. amblycarpa, namun untuk $C$. aurantiifolia mempunyai kerapatan yang lebih rendah dibandingkan dengan penelitian ini.

Menurut Boso et al. (2016), tinggi rendahnya kerapatan stomata tidak selalu dipengaruhi oleh ukuran daun, karena stomata yang sangat rendah dapat dijumpai pada daun yang lebar seperti pada tanaman Castanal. Beberapa peneliti melaporkan bahwa, perbedaan kerapatan stomata dapat dipengaruhi oleh factor eksternal, seperti habitat, intensitas cahaya dan ada tidaknya naungan (Loumala et al. 2005). Kelembaban juga berpengaruh terhadap kerapatan stomata, pada tempat yang lembab maka kerapatan stomata lebih rendah (Zhu et al. 2018).

Tabel 3 menyajikan Indeks Stomata (IS) dan distribusi stomata. Indeks stomata pada 5 jenis Citrus yang diamati menunjukan variasi dengan rentang $28.97 \%$ sampai $33.21 \%$. Tinggi rendahnya indeks stomata pada suatu tumbuhan dipengaruhi oleh jumlah stomata dan jumlah sel epidermis. Semakin tinggi jumlah stomata dibandingkan jumlah sel epidermis, maka semakin tinggi Indeks stomatanya (Mulyani 2006).

Tabel 3. Indeks dan distribusi stomata

\begin{tabular}{clcc}
\hline No & \multicolumn{1}{c}{ Jenis } & IS (\%) & Distribusi \\
\hline 1. & C. amblycarpa & 28.97 & Tersebar \\
2. & C. aurantiifolia & 32.72 & Tersebar \\
3. & C. hystrix & 29.57 & Tersebar \\
4. & C. limon & 31.82 & Tersebar \\
5. & C. microcarpa & 33.21 & Tersebar \\
\hline
\end{tabular}

Berdasarkan tabel 3 di atas, dapat diketahui bahwa indeks stomata tertinggi ditemukan pada C. microcarpa (33.21\%) dan terendah pada $C$. amblycarpa (28.97). Indeks stomata jenis $C$. aurantifolia dan C. microcarpa yang ditemukan pada penelitian ini lebih tinggi dibandingkan dengan hasil kajian Tuasamu (2018), dengan indeks stomata 26.6\% dan $19.34 \%$. Namun indeks stomata $C$. hystrix lebih rendah dibandingkan hasil penelitian tersebut (37.39\%). Hasil kajian Obiremi dan Olabele (2001) pada 6 jenis Citrus di Africa menunjukan Indeks stomata yang rendah pada semua jenis. Misalnya $C$. limon hanya mempunyai indeks stomata $16.8 \%$, dan C. autantifolia $17.3 \%$. Sampel yang diambil pada penelitian tersebut berasal dari daerah yang lebih kering, sehingga diperkirakan mempengaruhi indeks stomata Citrus.

Sedangkan distribusi stomata semua jenis Citrus pada penelitian ini adalah tersebar, yang artinya bahwa stomata ditemukan pada merata pada permukaan daun. Distribusi stomata Citrus hanya ditemukan pada permukaan bawah daun (abaxial), sehinga mempunyai tipe stomata hipostomatik. Tipe ini merupakan salah satu adaptasi tumbuhan terhadap lingkungan, untuk mengurangi laju transpirasi.

\section{Ukuran stomata}

Gambar 4 dan 5 menunjukan histogram panjang dan lebar stomata 5 jenis Citrus yang diteliti. Ukuran panjang dan lebar terbesar dijumpai pada C. microcarpa, sedangkan ukuran terkecil pada C. limon.

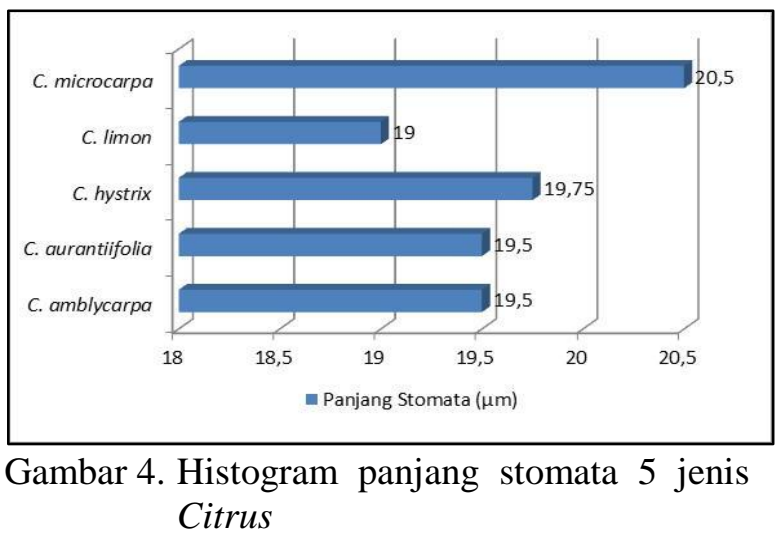




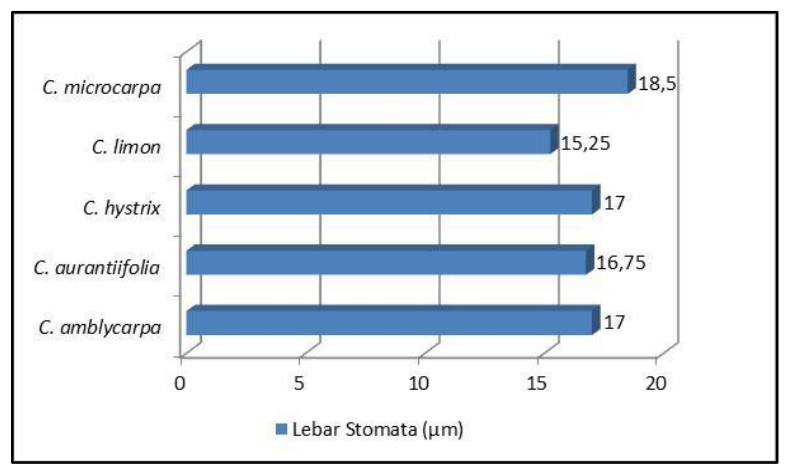

Gambar 5. Histogram lebar stomata 5 jenis Citrus

Ukuran panjang dan lebar stomata citrus pada penelitian ini, hampir sama dengan hasil penelitian sebelumya yang dilaporkan oleh Firdaus dan Maasawet (2015), seperti pada $C$. aurantiifolia dengan panjang stomata $22.5 \mu \mathrm{m}$ dan lebar stomata $15 \mu \mathrm{m}$. Namun pada penelitian Obiremi dan Olabele (2001), ukuran stomata pada $C$. limon dan $C$. autantifolia lebih besar (23.6 dan $24.9 \mu \mathrm{m}$ ) dibandingkan hasil kajian ini. Menurut Drake et al. (2013), ukuran stomata yang lebih kecil akan memberikan respon yang cepat terhadap lingkungan dibandingkan ukuran stomata yang besar. Hasil penelitian ini menunjukan bahwa karakteristik stomata 5 jenis Citrus bervariasi pada kerapatan, indeks dan ukuran stomata. Sedangkan tipe dan bentuk stomata semua jenis menunjukan kesamaan.

\section{Kesimpulan}

Tipe dan bentuk stomata yang ditemukan pada 5 jenis Citrus yang diteliti menunjukan kesamaan yaitu tipe hipostomatik dengan stomata berbentuk ginjal. Variasi ditemukan pada kerapatan, indeks dan ukuran stomata.

\section{Ucapan Terima Kasih}

Penelitian ini didanai oleh KEMENDIKBUD RISTEK melalui PDUPT 2021 (No. 462/UN.19.1.5.3/PT.01.03/2021).

\section{Referensi}

Aina, D.O., Malik, M. (2013). Stomatal Complex and Transpiration Rates in Some Members of Rutaceae and Myrtaceae. Asian Journal of Biological and Life Sciences 2(2):170175. https://www.ajbls.com/sites/default/files/ AsianJBiolLifeSci_2_2_170.pdf.

AL-Anbari, K., Sahapat, B., Pimwadee, P. \& Piyada, T. (2015). Pollen grain morphology of Citrus (Rutaceae) in Iraq. Aseel. International Conference on Plant, Marine and Environmental Sciences (PMES-2015).

https://www.researchgate.net/publication/ 283498753_Pollen_grain_morphology_of _Citrus_Rutaceae_in_Iraq.

Avci, N \& Aygün A. (2014). Determination of Stomatal Density and Distribution on Leaves of Turkish Hazelnut (Corylus avellana L.) Cultivars. Tarim Bilimleri Dergisi. 20. 454-459. 10.15832/tbd.27845.

Drake, R., Froend H. \& cowan E. (2013). Smaller faster stomata: scaling of stomata size, rate of response, and stomatal conductance. Journal of Experimental Botany 64(2): 495-505.

https://academic.oup.com/jxb/article/64/2 $\underline{1495 / 531702}$

Firdaus M, \& Maasawet ET. (2015). Perbedaan Ukuran dan Bentuk Stomata Tumbuhan Air dan Tumbuhan Darat. Prosiding Seminar Nasional I Biologi, Sains, Lingkungan, dan Pembelajaran. Samarinda: Universitas Mulawarman.

Haryanti, S. (2010). Jumlah dan distribusi stomata pada daun beberapa spesies tanaman dikotil dan monokotil. Buletin Anatomi dan Fisiologi, 18 (2), pp. 21-28. https://media.neliti.com/media/publicatio ns/60035-ID-jumlah-dan-distribusi-

stomata-pada-daun.pdf.

He J \& Liang Y. (2018). Stomata. In: eLS. John Wiley \& Sons, Ltd: Chichester. DOI: 10.1002/9780470015902.a0026526

Hussain SZ, Naseer B, Qadri T, Fatima T, \& Bhat TA. (2021). Citrus FruitsMorphology, Taxonomy, Composition and Health Benefits. Fruits Grown in Highland Regions of the Himalayas. Pp 229-244. 
Inyama CN, Osuoha VUN, Mbagwu FN, \& Duru CM. (2015). Comparative Morphology of the Leaf Epidermis in Six Citrus Species and It's Biosystematics Importance. Medicinal \& Aromatic Plants 4(3):1-5. DOI: $10.4172 / 2167-0412.1000194$.

Karubuy, C.N.S., Rahmadaniarti, A. \& Wanggai, J. (2018). Karakteristik Stomata Dan Kandungan Klorofil Daun Anakan Kayu Cina (Sundacarpus amarus (Blume) C.N.Page) Pada Beberapa Intensitas Naungan. Jurnal Kehutanan Papuasia 4 (1): 45-56.

Kirkham, MB. (2014). Stomatal Anatomy and Stomatal Resistance in Principles of Soil and Plant Water Relations (Second Edition).

Luomala E., Laitinen K., Sutinen, S., Kellomäki, S. \& Vapaavuori, E. (2005). Stomatal density, anatomy and nutrient concentrations of Scots pine needles are affected by elevated $\mathrm{CO} 2$ and temperature. Plant, Cell and Environment 28: 733-749.

Mabberley, D.J. (2004). Citrus (Rutaceae): A Review of Recent Advances In Etymology, Systematics And Medical Applications1 Blumea 49: 481-498. DOI: $10.3767 / 000651904 X 484432$.

Mashau A, Fish L, Wyk A. (2013). Poaceae. Bothalia 43(1): $71 \quad-\quad 75$. 10.4102/abc.v43i1.109.

Musara, C., Aladejana, E., \& Mudyiwa, S. (2020). Review of the nutritional composition, medicinal, phytochemical and pharmacological properties of Citrus reticulata Blanco (Rutaceae). F1000 Research. 9: 1-11. DOI: 10.12688/f1000research.27208.1.

Obiremi, E.O. \& Oladele, F. (2001).Water conserving stomatal systems in selected Citrus species. South African Journal 67: 258-260.

Richardson, F., Brodribb, T.J., Jordan, G.J. (2017). Amphistomatic leaf surfaces independently regulate gas exchange in response to variations in evaporative demand, Tree Physiology 37(7): 869878. https://doi.org/10.1093/treephys/tpx0 73.

Tuasamu, Y. (2018). Karakterisasi Morfologi Daun dan Anatomi Stomata pada Beberapa Spesies Tanaman Jeruk (Citrus sp.). Jurnal Agribisnis Perikanan 11(2):85-90.

Ulukuş, D. \& Tugay, O. (2018). Haplophyllum ermenekense (Rutaceae), a new species from Turkey. PhytoKeys 111: 119-131. 10.3897/phytokeys.111.24241.

Wallis TE. (1965). Analytical Microscopy: Its Aims and Methods in Relation to Foods, Water, Spices and Drugs. Boston: Little Brown and Company.

Yulianti F, Adiredjo AL, Soetopo L, \& Ashari S. (2020). Morphology and genetic characteristics of potential citrus rootstock in Indonesia. Biodiversitas. 21(11): 55145520. DOI: 10.13057/biodiv/d211160. 